\title{
DEVELOPING GENERIC SKILLS AT UNIVERSITY, DURING WORK PLACEMENT AND IN EMPLOYMENT: GRADUATES' PERCEPTIONS
}

Gay Crebert, Griffith Institute for Higher Education, Griffith University Merrelyn Bates, School of Criminology and Criminal Justice, Griffith University Barry Bell, School of Leisure Studies, Griffith University Carol-joy Patrick, School of Microelectronic Engineering, Griffith University Vanda Cragnolini, Griffith Institute for Higher Education, Griffith University

Correspondence should be addressed to:

Dr Gay Crebert

Griffith Institute for Higher Education

Griffith University, Mt Gravatt Campus

Qld 4111

Email: G.Crebert@mailbox.gu.edu.au

Phone: (07) 38755981 or (07) 38482367 


\title{
DEVELOPING GENERIC SKILLS AT UNIVERSITY, DURING WORK PLACEMENT AND IN EMPLOYMENT: GRADUATES' PERCEPTIONS
}

\begin{abstract}
This paper presents findings from Stage 4 of the Griffith Graduate Project. Graduates from three Schools within Griffith University were surveyed to determine their perceptions of the contributions that the learning contexts of university, work placement and post-graduation employment made to the development of their generic skills. All graduates involved in the project had experienced work placement as a formal part of their undergraduate studies. Supplementary data from focus group discussions held with employers and graduates are also included. Findings showed that while graduates recognised the contribution university had made to their generic skills development, they greatly valued the experience of learning in the workplace during placement and subsequently in employment. The importance of teamwork, being given responsibility and collaborative learning emerged as the most important factors for effective learning in the three contexts under consideration.
\end{abstract}

\section{Introduction}

The Griffith Graduate Project ${ }^{1}$ commenced in 1999 as an integrated suite of projects designed to raise awareness of generic skills, collect data on current levels of their implementation, embed them into the curriculum and develop ways to assess, monitor and record progress at Griffith University. As well as raising awareness of the importance of generic skills, not only for employment prospects but for the development of the whole person, the project's focus, in its first three stages, was on the "life cycle" of the student throughout the degree program and beyond. Stage 4 of the project extended the generic skills research to explore the relationship between undergraduate programs which include components of work placement, and the graduates' employing workplace.

A number of studies (Atkins,1999; Bennett, Dunne \& Carré, 2000; Gallagher, 2000; Harvey, Moon \& Geall, 1997) found that the expectations of employer groups in relation to university education appear to be strongly influenced by highly context-bound interpretations of desirable graduate attributes, capabilities, competencies and the like. As Clanchy and Ballard (1995) argue, it is clearly unrealistic for universities to guarantee that their students will graduate in possession of all the desirable generic skills and attributes spelt out in their institutional documentation. Such guarantees would, in all likelihood, leave universities vulnerable to litigation in the most extreme cases. However, what universities should guarantee is that their students will all have the opportunity to learn and develop generic skills and abilities during their undergraduate study. How well they do this depends largely on individual attitudes and motivation, not only of teaching staff, but also of students themselves.

Harvey, et al (1997) and Te Wiata (2001) found that students' ability to integrate and demonstrate generic skills was linked to the development of confidence in their application to new and different contexts, including the workplace. In Australia, there are a number of

${ }^{1}$ The Griffith Graduate Project has been funded by Griffith University’s Quality Enhancement and Strategic Development Grants Schemes. 
institutions (notably those from the Australian Technology Network, The University of Wollongong and The University of Newcastle), which go to great lengths to promote the importance of generic skills to their students. At the same time, in other external contexts, students develop personal and professional skills while living away from home, travelling, doing voluntary or community work, and participating in clubs and societies, that impact upon their confidence and consequently increase their employability (Atkins, 1999). Even if these learning experiences can be harnessed and translated back into the classroom through critical reflection, it is usually not until they are included in students' learning objectives and formally assessed, that their importance for their future careers is fully accepted by students (Bennett, et al, 2000).

The spate of reports commissioned by higher education stakeholders over the past ten years (e.g., AC Nielsen Research Services, 2000; Business/Higher Education Round Table [B/HERT], 1991, 1992, 1993; Coopers \& Lybrand, 1998; Sausman \& Steel, 1997; The Association for Graduate Recruiters, 1993, 1995) have all recognised that a strong disciplinary knowledge base does not, of itself, guarantee a new graduate a job. For example, Harvey's research (1999) in the United Kingdom highlighted that it was the "graduate attributes" which were perceived to be the variable that determined a graduate's success in the workplace, rather than their specific degree. Given that many universities are now deliberately emphasising this to students, especially as they approach their final year, the ability to transfer and apply knowledge and skills learned at university into the workplace is becoming more and more important.

The notion of transferability has been a contentious issue in the literature for a number of years (Clanchy \& Ballard, 1995; Eraut, 1994; Oates, 1992; Tennant, 1999), with most of the debate revolving about whether or not skills learned in one context can be transferred into another, in which the "task, people and expectations" (Atkins, 1999, p. 275) may be so different as to require a completely new approach to learning, and its transfer and application in new contexts. What is clear is that the so-called "generic" skills and abilities cannot be learned or developed outside a disciplinary context (Clanchy \& Ballard, 1995), but that transfer and application between contexts can, and do, occur where facilitative teaching of the "meta-skills," or skills of transfer (Honeybone, Blumhof, Hall \& Palmer, 2001), occurs.

In utilising the work placement as an opportunity to reinforce the application of generic skills learned in the classroom, students can be required to reflect critically on and analyse their experiences in conjunction with both the academic and workplace supervisors. Such a model supports the principles of lifelong learning, situated learning, or learning in context (Brown, Collins \& Duguid, 1989), and transformative learning (Harvey, 1999). Atkins (1999, p. 276) develops this theme further when he argues that "employer defined projects" provide the opportunity for students to employ both their discipline-specific knowledge and their "generic skills and personal attributes in a context closer to that which [they] will encounter after graduation.”

Most research into the role of the practicum in higher education has focussed on three main aspects: the educational value of the work placement for the student; the interest taken by academic staff in their students' perceptions of the placement; and the benefits of the placement for students' future careers (Cameron-Jones \& O’Hara, 1999). While the work of Ryan, Toohey and Hughes (1996) and Toohey, Ryan and Hughes (1996) explored some of the generic skills 
issues in the context of the practicum, there have been few comparative studies of the effect of context on skills development at university, during work placement and in post-graduation employment. Most studies have taken as their main focus one or other of the three contexts. For example, Arnold, Loan-Clarke and Harrington (1999) compared the perceptions of students in different branches of management at six UK universities with those of employers, in order to identify "the roles of placements and academic work in the development and employability of undergraduate students” (Arnold et al, 1999, p. 48). Though this was a comparative study, it did not consider the perceptions of employed graduates. It aimed to determine whether "the extent to which the competences students perceive as being most developed in placements and academic work are those which employers most look for in selecting graduate recruits.” Its final conclusions were interesting and to the negative.

Until recently, one of the few investigations into the longitudinal benefits of the experience for graduates' skill development in employment was that conducted by Harvey, et al (1997), in which 258 interviews were conducted with strategic managers, line managers, graduate and nongraduate employees in 91 organisations. It found that "respondents overwhelmingly endorsed work-based placements as a means of helping students develop attributes that would help them to be successful at work” (Harvey, et al, 1997).

Other studies have involved employers in an attempt to identify stakeholder expectations of university graduates. Bennett, Dunne \& Carré (2002), in a project for the UK Economic and Social Research Council, explored employers' perspectives on the role of generic skills in the workplace and the different uses, purposes and contexts for their development in the first few years of graduate employment. They found that there was widespread confusion among university academics in the nature and purpose of generic skills in higher education, and that employers and employees alike had varying understandings of their importance in the workplace. Significantly, the data they gathered from new graduate employees showed that:

The most important sources of employee learning derived from the challenges of the work itself and from interactions with others in the workplace. For example, graduate employees identified that the major skill to be learned was to "fit in". This meant adapting to cultural expectations and organisational pressures, and learning the "language of the job”, and such differences in context and demand affected the skills used.

In Australia, Martin (1997) examined the quality of various models of course provision for workbased education and found that student satisfaction with the work placement was closely linked to the mutual support of both academic and workplace supervisors. More recently, a research study by The University of Technology, Sydney (Scott \& Yates, 2002 cited in Lawnton, 2002) has undertaken "backward mapping" based on the experiences of high achieving graduates from a number of discipline areas to improve curriculum design, and teaching and learning practices. Findings from this study in relation to engineering graduates point to the importance of generic skills, particularly teamwork, in the undergraduate curriculum.

These and other findings have contributed to the rapidly growing body of literature on stakeholders' expectations of higher education (e.g., Bridges, 2000; Holmes, 2001). With remarkable consistency, the reports emphasise employers' stated needs for graduates to be able 
to function in the workplace, be confident communicators, good team players, critical thinkers, problem solvers and, in addition, to be adaptive, adaptable and transformative people capable of initiating as well as responding to change (Harvey, et al, 1997). Even though the desirable graduate attributes stated by employers in these lists vary little from those of the 1970s (Harvey, 1999), it appears that the lists are getting longer and longer, and more and more complex. Harvey, et al (1997) also suggest that as graduates become more aware of the potential workplace expectations, there are some who do not believe they can meet them and "become demoralised.”

Whether or not employers have set unrealistic expectations and whether or not they are even clear in their own minds about what they actually expect from a new graduate is open to debate. Given that jobs in this century will be vastly different from any that have preceded them, perhaps it is time for employers and universities to reconceptualise the kinds of generic skills and abilities that are considered necessary for the new graduate. Atkins (1999) suggests that with research identifying that "graduates in the next century are likely to be knowledge workers and symbolic analysts, service providers, members of learning organizations, and managers of their own careers," there is an opportunity to begin to "cluster a combination of subject-specific skills and knowledge, generic intellectual skills, generic process skills, competencies and personal attributes” (Atkins, 1999, p. 277). To explore the perceptions of graduates from Griffith University about the importance of generic skills in their career development, a project brief was designed.

\section{Project aims}

The broad aim of Stage 4 of the Griffith Graduate Project was to identify how university study, work placements and post-graduation employment develop generic skills. More specifically, the project aimed to determine, from survey responses and focus group interviews, the perceptions of graduates and employers on the following issues:

- What generic skills are best developed in a university context;

- How these generic skills might be better developed in a university context;

- The extent to which the graduates' generic skills were developed at university;

- What generic skills are best developed in the workplace context;

- How the graduates' abilities and capacities [as listed in the Characteristics of a Griffith Graduate statement ${ }^{2}$ ] were enhanced or modified through professional work placements/practicums linked to their university course; and

- How their generic skills developed through post-graduation employment.

\section{Methodology}

\section{Participating Schools}

\footnotetext{
2 The Griffith Graduate Statement lists as desirable graduate generic skills and abilities: oral and written communication; problem solving; analysis; critical evaluation; information literacy; teamwork; undertaking independent lifelong learning; initiating and leading enterprises; assuming responsibility and making decisions; undertaking employment or further study nationally and internationally; and demonstrating high ethical standards.
} 
Three Griffith University Schools participated in the project: Microelectronic Engineering; Criminology and Criminal Justice; and Leisure Studies. Common across all three programs is the opportunity for students to develop an awareness and application of a variety of generic skills through work placements offered as part of their degree programs. The three work programs also share the following features:

- Integration of the work placement in the undergraduate program (e.g., credit points are allocated);

- Provision of both an academic and workplace supervisor for the student on placement;

- Allocation of a staff member to take responsibility for coordinating the program between School and industry;

- Formal assessment by the University of the students' learning outcomes from work placement; and

- Acceptance of a fair degree of responsibility by students for negotiating and managing the placement process, as part of their professional development.

\section{Focus group discussions}

Two focus group discussions were held with a sample of 11 graduates and six employers. The graduates were selected at random from the database of subjects, and the employers, representing the public and private sectors (including large, medium and small enterprises), were identified by the relevant academic staff members in the participating Schools. The discussions were held separately, using identical questions and prompts, and sought the participants' opinions on: the generic skills best developed in a university and workplace context; how these skills can be better developed at university; their level of satisfaction with the development of these skills at Griffith University; how a work placement enhances students' generic skills development; and how employment after graduation further develops graduates' generic skills. Each discussion was audio-taped, with the permission of the participants, and later transcribed for thematic analysis. There was consistency between comments from the two groups, especially in relation to: the benefits of employer involvement in curriculum development and delivery; the valuable networking opportunities provided by work placements; and the greater importance employers place on generic and interpersonal skills than on content knowledge and academic qualifications during the recruitment process.

\section{Survey}

\section{Graduate sample}

A data-base of 664 graduates who had completed work placements in the respective degree programs between 1997 and 2000 was constructed. A questionnaire survey was designed for electronic and hard-copy transmission and follow-up notices and emails to the graduates were sent after two weeks. An initial covering letter referred the graduates to the Griffith Graduate web site (http://www.gu.edu.au/centre/gihe/griffith_graduate/) for background information and definitions of the terminology used in the survey instrument. 
Respondents

Demographic data collected from the survey are reported in Table 1 below. :

[Table 1 about here]

Survey instrument

The survey instrument included a total of 32 questions: 11 required responses on a five point Likert scale, where 1 represented "Strongly Disagree" and 5 represented "Strongly Agree"; nine required a simple check box response; nine offered the opportunity for text responses; and three required prioritisation by entering rank-ordered numbers in the relevant spaces.

The questionnaire was divided into six sections. Section 1 collected demographic information; Section 2 collected graduates' perceptions of their development of generic skills and abilities while at university; Sections 3 and 4 collected similar data in relation to their university work placement and post-graduation employment respectively; Section 5 required reflection on the three different learning contexts and prioritisation; and Section 6 allowed for additional comments on any aspect of generic skills development and/or the questionnaire.

\section{Results}

Table 2 presents data on each of the questions that used a five point Likert scale, and one that required a Yes/No answer.

[Table 2 about here]

Results from the survey questionnaire are reported in full on the Griffith Graduate web site: http://www.gu.edu.au/centre/gihe/griffith_graduate and only some are discussed in the following section in response to the research questions the project aimed to address, namely:

What generic skills are best developed in a university context and how might they be better developed? (Questions 2, 3 and 6)

There was agreement from 78.9\% of the graduates in Question 2 that they had had sufficient opportunities to develop their generic skills while at university. Many of their in-text comments referred to the scope provided to develop oral and written communication skills, critical analysis and evaluation, problem solving and teamwork skills. Aggregated responses to a question which asked them to identify the ways in which they best developed particular generic skills at university showed that group work was their preferred option for the development of oral communication, problem solving, teamwork, leadership, assuming responsibility and making decisions and high ethical standards.

Among the most frequently mentioned suggestions for improvement for generic skills learning activities from the graduates at university were a desire for: greater practical emphasis in undergraduate courses; more work placements; greater input from industry; more oral 
presentations, written assignments, project work, leadership training and case studies; more practice with information technology; and a greater emphasis on business administration skills.

The aggregated results on Questions 3 and 6 showed that the majority of graduates (65.2\%) felt that teaching staff had made them aware of the importance of generic skills.

\section{What generic skills are best developed in the workplace context? (Question 5)}

A higher percentage (82.5\%) of graduates recognised the opportunities offered during work placement for skills development, with one commenting that it "provided a framework for developing skills needed to adapt to different work environments," and another saying that “... work placement provided opportunities to utilise these skills and abilities I developed in a workplace situation. It provided valuable feedback from industry regarding the level of skill I had acquired through my university studies." When their responses to a question which asked them to identify the ways in which they best developed particular generic skills during work placement were collated, working collaboratively with colleagues emerged as their preferred option for the development of problem solving, analysis, teamwork, leadership, assuming responsibility and making decisions and high ethical standards.

Written suggestions for improvement of skills development during work placement related to improving the quality of work placement and academic supervision, and increasing the opportunities to develop teamwork and project management skills. Some graduates would have preferred more interaction with a mentor during placement, and others more group/teamwork activities, and active participation in workplace meetings and decisions.

How were the graduates' abilities and capacities were enhanced or modified through professional work placements/practicums linked to their university course? (Questions 1, 4, 7 , $8,11,12$ and 14)

Slightly over half of the graduates who responded to Question 1 (55.3\%) felt that it was more important for their future career prospects to develop generic skills and abilities at university than to acquire content knowledge. They gave a similar level of endorsement (53.5\%) to the value of work placement in enhancing employment prospects after graduation (Question 4), and were only slightly more convinced (59.5\%) that their generic skills had contributed directly to finding employment after graduation (Question 12). While none of these results is particularly noteworthy, the fact that $98 \%$ of the graduates recognised the importance of on-going generic skills development in the workplace (Question 8) was both interesting and well supported by intext and focus group comments. Graduates referred to a number of different professional development opportunities they had engaged in during the early years of their employment, and there was general agreement that the range and number of such opportunities depended largely on the attitude of their employer or supervisor. One graduate commented:

If your employer doesn't give you the opportunity or have the facilities for you to transfer your generic skills, then you've got Buckley's chance of developing them, or of bringing your skills in. I suppose it's to do with attitude as well. 
Data gathered in the course of this study suggested that there was a correlation between the graduates' experience of work placement and the relative ease with which they made the transition from university to employment. The graduates' responses to Question 7 showed that $78.5 \%$ had been required to apply the generic skills learned at university while on placement, and that $72.6 \%$ had not encountered major difficulties in moving between the two contexts (Question 11). There was a strong perception (74.2\% agreement with the statement in Question 14) that the skills developed during work placement had made a significant contribution to the graduates' subsequent career advancement. These findings suggest that work placements, as well as providing networking opportunities and work experience, offer a valuable preparation for the kinds of problems and difficult situations that the new graduate employee often encounters.

How were their generic skills developed through post-graduation employment? (Question 9)

Once they had entered employment, the majority (77.2\%) of the graduates were satisfied with the opportunities available for on-going skills development and cited in-house continuing professional development seminars and workshops, short training courses, graduate programs, etc. as examples. Development opportunities depended largely on available resources within the organisation, the employer's attitude and the graduate's own initiative, e.g.:

So it depends on the priorities of the workplace as to what generic skills you get developed. You obviously get your own priorities on top of that as well, so you develop in those areas more so, and then others as you learn to work with other people.

When their responses to a question which asked them to identify the ways in which they best developed particular generic skills in employment, collaboration emerged as their preferred option for the development of problem solving, analysis, teamwork, leadership, assuming responsibility and making decisions and high ethical standards. Comments indicated that they were aware of the need to be on-going, lifelong learners, that they needed to be able to transfer generic skills from one context to another and develop them specifically to meet different requirements.

Consistently, the graduates in our study identified interactive group work and collaboration as the most effective ways to develop generic skills in the three different learning contexts.

\section{Discussion}

The questionnaire data indicated that the graduates whom we surveyed distinguished quite clearly between the three contexts of university, work placement and employment as sites of learning, each with unique characteristics and requirements. They were able to reflect, in depth and in hindsight, on what each one had contributed to their overall generic skills development. Issues relating to each of the learning contexts are now discussed. "The workplace" here refers to both contexts of work placement and post-graduation employment.

\section{University}


Throughout the survey responses, there was a strong emphasis on the importance of interactive group learning at university for the development of generic skills and abilities, in formal, assessable teamwork exercises or group projects. However, while recognising the value and importance of teamwork skills, not all the graduates had confidence in their abilities to work in a team at the start of employment and were critical of how process aspects of teamwork had not been paid enough attention at university. One graduate said, for example:

At university, you could actually circumvent the teamwork thing and just be an individual. You'd still pass and go forward, but when you go into the workplace, others are relying on you and you are going to have to rely on them. You can't afford to impact on them, and you have to realise that you are responsible to them so that you can provide them with what they need.

To some extent, the prevailing culture of learning at university - a culture that values "personal achievement, personal ambition, personal goals, and most importantly, personal rewards," is at odds with learning in the workplace, where "team achievement, team goals and team results are vital to the success of the larger organisation, and [where] often individual needs and desires have to be subordinated to the collective goal” (Candy \& Crebert, 1991, pp. 582-3). Harvey (1999) also found that "graduates... need to be able to work effectively in teams as there is little demand in a flexible organisation for introspective, individualised working. Most organisations operate via project-oriented teams rather than individuals working in a traditional chain of responsibility.” An employer in our focus group disccusion made the contrast between learning at university, where the emphasis is on the student's needs, and learning in the workplace, where the emphasis is on the organisation's and the client's needs. This employer made the point that students on work placement need to understand that employers have other priorities and that meeting their own workplace deadlines takes precedence over reading through a student's report, even if it is due to be submitted for assessment to the university the next day.

Opportunities for teamwork in the undergraduate curriculum offer students not only the chance to develop leadership, interpersonal and communication skills, but also to practice ethical decision-making. Dunne (2000, p. 363) lists a number of other benefits of teamwork to students, universities and employers alike and argues that "the development of team- and groupwork is well worth supporting and fostering." However, as a general rule, little attention is paid by academics to the processes, roles and outcomes involved in effective teamworking (Dunne, 2000) and students often complain that they are thrown together in groups (often called project teams) in an attempt merely to reduce the lecturers' marking load.

During the focus group discussions, some of the graduates suggested generic skills should be given more emphasis in assessment items and that teaching staff should make the connections between various parts of the curriculum more explicit, in order to make stronger links between what the students were learning in the classroom and its practical application in the workplace (especially by using real world analogies and examples), e.g.,

One of the things that is really important, probably at the start of every lecture, every time they launch into a new topic, is to say "This is what we are going to be discussing. Now you might use this in this situation.” 
On the other hand, the promotion of critical reflection on learning was highlighted as one of the strengths of the graduates' learning at university. Each of the Schools includes a component of critical reflection on work placement learning and graduates in the focus groups certainly saw the value in structured debriefing and reflection sessions at university, making comments such as:

It comes back to putting a label on everything, and I think it does - a debriefing or a discussion, or anything like that - it tends to say, "These skills were somehow or other indirectly addressed or acknowledged."

Comments from the graduates in this study confirmed the need for deliberate, critical reflection on learning - learning not only at university, but in the student's broader social context. Orrell includes "reflection, debriefing on the work and monitoring of the quality of the outcomes" (2001, p. 4) in her list of distinguishing features necessary for a work placement to be effective and Harvey (1999, p. 26) argues that if students' learning is to develop through work placement, then what is needed is "systematic reflection."

As well as incorporating critical reflection into the curriculum, academic staff need to encourage students to seek out and negotiate opportunities for skills development while they are on placement, and during the placement students need to formalise the process of feedback on performance from their industry supervisor. At the same time, academics need to make clearer to employers and work placement supervisors the need to provide such opportunities, for, as Drummond, Nixon and Wiltshire (1998, p. 21) argue:

Established models of good practice suggest that effective skills development depends on opportunities to practice skills with support and guidance which encourages and informs constructive reflection and the definition of strategies for improvement. Self-assessment and feedback from peer groups are usually held to form a key component of this experiential learning process. Similarly, 'transferability' depends to a large extent on practising skills in a wide range of different contexts.

\section{The workplace}

In the workplace, the survey results showed that generic skills development was closely associated with the degree of responsibility the graduates were given by their supervisors and employers and with the extent of collaborative learning they were able to experience, either in group situations or one-on-one interactions. This suggests that students in these fields need to be given more opportunities for structured group and teamwork while they are at university, by way of preparation for the workplace. Only the development of information literacy and written communication skills were felt to be best developed independently.

Comments from the graduates and employers emphasised the importance of teamwork in the curriculum and confirmed the importance ascribed to it in the recent study by Scott and Yates (2002, cited in Lawnton, 2002) as a valuable means of developing other skills, such as critical thinking, problem solving and ethical awareness. Indeed, one or two of the employers at our focus group discussion felt strongly that industry professionals should be involved in setting the 
problems that students are required to solve in class so that they would be "real world" and multidimensional, involving complex ethical issues as well as technical knowledge. The resource-intensive implications of such a shift in curriculum focus cannot be underestimated, however. A shift of this magnitude involves major changes in curriculum design and teaching practices, and usually invokes considerable resistance from already pressured academic staff (Dunne, 2000).

Our findings suggest that more needs to be done at university to ensure that collaborative learning opportunities can be structured into the placement aims and learning objectives and, more importantly, into the placement supervision process. The graduates made frequent comments during the focus group discussion that being able to assume responsibility and make decisions about their own learning was a very significant factor in the development of their generic skills and abilities, but in general they felt there had not been sufficient opportunities for this in the university context. It is, of course, preferable that the work placement be structured as a worthwhile learning experience, but it is not always easy for academics and students to request employers to give temporary work placement students sufficient responsibility to ensure that their learning experience is both challenging to them and valuable to the organisation (Arnold, et $a l, 1999)$. The graduates involved in the focus group recognised this, with some even expressing doubts about their own ability to assume too much responsibility, e.g.,

I think it's difficult enough to expect an employer to take on a university practicum student and provide them with an opportunity that really pushes them to their limit, because it is a big risk. I think, as a student, I would feel the pressure if they put me on heading up or being involved in a project that had significant ramifications if it went wrong. For me, it is more about getting in there with the real live work environment, seeing real issues, real solutions and working with a team of real people.

Graduates' comments on learning while on work placement in this study confirmed the findings of Orrell (2001, p. 3), who argues that workplace learning enables students to:

- Identify the relevance of particular theoretical concepts, skills and ways of proceeding that have been learnt in their course of study, and thus encourage more intentional classroom learning;

- $\quad$ Put theory into practice;

- Appreciate that academic success is not the only attribute for successful employment and careers;

- Develop an awareness of workplace culture and appreciate the rapidly changing nature of the world of work;

- Evaluate and develop work-related personal attributes (diplomacy, cooperation, workplace etiquette and leadership);

- Develop specific communicative and interactive abilities;

- Establish career plans and strategies.

While the majority of the graduates in both the survey and focus groups indicated that their work placement experiences carrying out specific, “employer defined projects” (Atkins, 1999, p. 276) had been extremely valuable, a few graduates commented that they had not had sufficient 
opportunities to do "worthwhile" work during placement, but instead had been required to do mundane, routine tasks such as photocopying and data entry. This suggests that there needs to be closer liaison between the academic and workplace supervisor to provide "meaningful work" (Orrell, 2001, p. 4) for students on placement - i.e., work experiences in which students receive the optimal mix of high levels of support and challenge in the workplace (Daloz, 1986, cited in Cameron-Jones \& O’Hara, 1999).

The application of generic skills and abilities during work placements creates a number of problems for students and their academic and workplace supervisors, more often than not associated with assessment - how, and by whom it is done. Toohey, Ryan and Hughes (1996, p. 216) express it in the following way:

Many of the problems surrounding assessment of the practicum arise out of an inability to reconcile traditional assessment practices with the kinds of learning outcomes that might be expected from the practicum. University education has usually favoured knowledgebased assessment and assessment methods which enable comparison and ranking of students. Ideally, the practicum offers students the opportunity to apply knowledge, test theory and consequently modify their understanding. Insights and understandings of this nature may be difficult for students to express and certainly do not lend themselves to simplistic assessment. Assessment methods such as journals, analytical papers and oral examinations which allow for exploration and insight are the methods most demanding of students and assessors.

It was clear that some of the graduates felt there was room for improvement in the way in which students negotiate the placement learning objectives (including the mode of assessment) and how they are conveyed to the work placement supervisor so that maximum learning can occur. The employers in our focus group felt that generic skills should definitely be included in students' placement learning objectives; however, while they were willing to provide mid-placement formative assessment and feedback, they were not ready to commit themselves to summative marking affecting the student's formal academic record. It needs to be emphasised to the work placement supervisors that the placement itself is a valuable means of developing the generic skills and abilities that industry so frequently states it needs in its new graduate employees; and that the placement provides valuable opportunities for some degree of joint assessment negotiated by academic and workplace supervisors.

While our survey results indicated that $72.6 \%$ of the graduates had not experienced difficulty in transferring their skills from university to the workplace, some graduates in the focus group commented that their university lecturers had not prepared them adequately to transfer the generic skills and abilities to the workplace, e.g.,

If they would only teach you how these skills, or what we discuss in the theory, can apply to a variety of situations, and if you understood that concept and you'd been taught it, then to [take them] into the workplace I think would be fairly easy, [and you could] apply them to what you are doing, or to different areas. 
It is possible that generic skills development during employment could be enhanced if the skills of transfer - learning how to learn, awareness of context, capacity to move between different viewpoints, languages and systems of knowledge, self-regulation and critical self-reflection (Marginson, 1994) received greater emphasis at the undergraduate level. Some graduates commented in the focus group discussion that their on-going development depended largely on the attitude of the employer, the resources and facilities available in their workplace, and on whether the employer was prepared to give the new employee sufficient responsibility to develop new skills and abilities, e.g.:

It really depends on the company, because some companies will just set up all the hoops and say, "Jump through these; this is your job," and others will say, "Here is a ball - go run with it.”

The positive result on skills transferability in Question 11 suggested that graduates from these three Schools had received good preparation for learning in the workplace (through critical reflection as well as preparation and debriefing sessions) and it may well support in practice the theoretical findings put forward by Tennant (1999, p. 177), namely that transfer can and does occur when:

- Learners are exposed to 'authentic' activities, with the opportunity to access the full range of learning resources.

- Learners are exposed to multiple situations and multiple examples.

- Attention is drawn to the potential for transfer by highlighting the generic nature of the skill being acquired.

- The higher-order skills and principles being acquired are identified and made explicit.

- A supportive climate exists in the transfer context (e.g., supervisor support, opportunity to use learning, peer support, supervisor sanctions, positive personal outcomes, encouragement of further learning).

- There is a capacity to 'learn how to learn from experience', that is practice in analysing experience and developing strategies for learning.

- There exists a community of discourse (i.e., a common way of talking) in which all members are actively engaged in learning through communicating.

- Learners have 'lifelong learning' skills and dispositions (the capacity to be self-directed and control and regulate one's own learning).

\section{Conclusion}

The six research questions that the project aimed to address provided data that for the most part confirmed findings from the literature on the relationship between work placements, skills transferability and on-going generic skills development during employment. It was clear that some generic skills and abilities (notably communication skills, problem solving, analysis and teamwork skills) lend themselves to development at university, provided students are made aware of their importance, and are given opportunities to practise them throughout their degree programs and in an authentic workplace setting. 
Graduates and employers felt strongly that industry involvement in all aspects of the undergraduate curriculum was beneficial, particularly because it exposed students to "real world" problems and gave them experience in meeting deadlines and managing their time. Stronger linkages between curriculum content and "real world" examples and applications were repeatedly mentioned by graduates as a means of developing generic skills in the university context.

Leadership and entrepreneurial skills, assuming responsibility and making decisions, and demonstrating high ethical standards were felt to be more appropriately developed in the workplace, either during work placement or in an employment situation, than at university where opportunities were more limited. Work placements provided an excellent platform from which students could progress to the workplace and seek further opportunities for their development. The majority of graduates were satisfied with the range and number of opportunities their employers provided for professional and skills development.

Overall, the findings from Stage 4 of the Griffith Graduate Project supported the inclusion of work placements in undergraduate degree programs, both in terms of their development of students' generic skills and abilities and their provision of opportunities for employment and career development. The findings suggested that in the process of integrating generic skills and abilities into the undergraduate curriculum, the input and views of employers and graduates should be considered in relation to program development, not only as part of program accreditation and review but at the level of teaching and assessing in courses. In particular, data from the survey and focus group discussion with employers suggested that involving industry representatives in problem-setting and formative assessment of students' generic skills during work placement would be very beneficial in preparing new graduates for the workplace.

Data collected in the course of this study underlined the importance of integrating the development and assessment of generic skills and abilities when designing the learning objectives of undergraduate programs and work placements and, even more importantly, of incorporating components of critical reflection on learning. The strong emphasis that was given to teamwork in the survey responses and focus group comments suggested that the implementation of well-structured processes for teaching students how to work collaboratively at undergraduate level is the single most important factor in ensuring the development of other, associated generic skills and abilities, not only at university but during work placement and in employment. With this in mind, it is crucial that academic staff feel confident in teaching teamwork skills and processes and that they are supported by comprehensive staff development opportunities and teaching resources.

The first four stages of the Griffith Graduate Project addressed some, but not all of these issues. Stage 5 of the project will use a similar methodology to the one reported in this paper to focus on graduates who did not experience work placements as part of their degree program. The comparative data that becomes available will inform future policy, planning and teaching learning processes for generic skills development at Griffith University. A further stage (The Griffith Graduate Project: Graduate Outcomes) will concentrate on teaching, learning and assessment practices at Griffith University to foster generic skills development in the undergraduate curriculum. 


\section{References}

AC Nielsen Research Services. (2000). Employer Satisfaction with Graduate Skills. Research Report. Evaluations and Investigations Programme, Higher Education Division. Canberra: Department of Education, Training and Youth Affairs.

Arnold, J., Loan-Clarke, J., \& Harrington, A. (1999). Students’ perceptions of competence development in undergraduate business-related degrees. Studies in Higher Education, 24 (1), pp. 43-54.

Atkins, M.J. (1999). Oven-ready and self-basting: Taking stock of employability skills. Teaching in Higher Education, 4(2), pp. 267-278.

Bennett, N., Dunne, E., \& Carré, C. (2000). Skills Development in Higher Education and Employment. Buckingham: SRHE \& Open University Press.

Bennett, N., Dunne, E., \& Carré, C. Developing skills in higher education and employment. ESRC Learning Society Programme. Retrieved from the World Wide Web, 15 April, (2002): http://www.staff.ncl.ac.uk/f.j.coffield/summaries/bennett.rtf

Bridges, D. (2000). Back to the future: The higher education curriculum in the $21^{\text {st }}$ century. Cambridge Journal of Education, 30(1), pp. 37-55.

Brown, J.S., Collins, A., \& Duguid, P. (1989). Situated cognition and the culture of learning. Educational Researcher, 18, pp. 32-42.

Business/Higher Education Round Table.(1991). Aiming higher. Commissioned Report No. 1. Melbourne: Business/Higher Education Round Table.

Business/Higher Education Round Table. (1992). Educating for Excellence. Commissioned Report No. 2. Melbourne: Business/Higher Education Round Table.

Business/Higher Education Round Table. (1993). Graduating to the workplace: Business students' views about their education. Commissioned Report No. 3. Melbourne: Business/Higher Education Round Table.

Cameron-Jones, M., \& O’Hara, P. (1999). Student perceptions of the way that they are supervised during work experience: An instrument and some findings. Assessment and Evaluation in Higher Education, 24(1), pp. 91-103.

Candy, P.C., \& Crebert, R.G. (1991). Ivory tower to concrete jungle: The difficult transition from the academy to the workplace as learning environments. Journal of Higher Education, 62(5), pp. 570-592. 
Clanchy, J., \& Ballard, B. (1995). Generic skills in the context of higher education. Higher Education Research and Development, 14(2), pp. 155-166.

Coopers \& Lybrand. (1998). Skills Development in Higher Education. London: Coopers \& Lybrand.

Drummond, I., Nixon, I., \& Wiltshire, J. (1998). Personal transferable skills in higher education: The problems of implementing good practice. Quality Assurance in Education, 6(1), pp. 19-27.

Dunne, E. (2000). Bridging the gap between industry and higher education: Training academics to promote student teamwork. Innovations in Education and Training International, 37(4), pp. 361-371.

Eraut, M. (1994). Developing Professional Knowledge and Competence. London: Falmer Press.

Gallagher, M. (2000). The emergence of entrepreneurial public universities in Australia. Paper presented at the IMHE General Conference of the OECD Paris, September. Department of Education, Training and Youth Affairs, Higher Education Division: Occasional Paper Series 00/E. Retrieved from the World Wide Web, 17 May, 2002, http://www.detya.gov.au/highered/occpaper/00e/00e.pdf.

Harvey, L., Moon, S., \& Geall, V. (1997). Graduates’ Work: Organisational Change and Students' Attributes. Centre for Research into Quality. Retrieved from the World Wide Web, 17 May, 2002: http://www.ce.acu.uk/crq/publications/gw/gwcon.htm.

Harvey, L. (1999). New Realities: The Relationship between Higher Education and Employment. Keynote presentation at the European Association of Institutional Research Forum, Lund, Sweden, August. Retrieved from the World Wide Web, April 15, 2002: http://www.uce.ac.uk/crq/publications/cp/eair99.html

Holmes, L. (2001). Reconsidering graduate employability: The 'graduate identity' approach. Quality in Higher Education, 7(2), pp. 111-119.

Honeybone, A., Blumhof, J., Hall, M., \& Palmer, J. (2001). Integrating Skills Development with Academic Content in Higher Education. A Guide to the Work of the Hertfordshire Integrated Learning Project. University of Hertfordshire. Retrieved from the World Wide Web, April 15, 2002: http://www.herts.ac.uk/envstrat/HILP/

Lawnton, P. (2002). Smells like team spirit. The Australian, 24 April, p. 29.

Marginson, S. (1994). Is competency-based education a good enough learning framework? In Competency-based education: A compilation of views. Melbourne: Australian Education Union. 
Martin, E. (1997). The Effectiveness of Different Models of Work-based University Education. Canberra: Department of Education, Training and Youth Affairs. Retrieved from the World Wide Web, April 15, 2002:

http://www.detya.gov.au/archive/highered/eippubs/eip9619/front.htm

Oates, T. (1992). Core skills and transfer: Aiming high. Education and Training Technology International, 29(3), pp. 227-339.

Orrell, J. (2001). Work-integrated learning in universities: Cottage industry or transformational partnerships? Paper presented at the GIHE/IPON Symposium on Work-Integrated Learning, Griffith University, 30 October.

Ryan, G., Toohey, S., \& Hughes, C. (1996). The purpose, value and structure of the practicum in higher education: A literature review. Higher Education, 31(3), pp. 355-377.

Sausman, C., \& Steel, J. (1997). The Contribution of Graduates to the Economy. Report No. 7 of the National Committee of Inquiry into Higher Education. London: HMSO.

Te Wiata, I. (2001). A big ask: To what extent can universities develop useful generic skills? In F.Bevan, C. Kanes, \& D. Roebuck (Eds). Knowledge Demands for the New Economy. Brisbane: Australian Academic Press, pp. 290-297.

Tennant, M. (1999).Is learning transferable? In D. Boud \& J. Garrick, Eds. Understanding Learning at Work. London: Routledge, pp. 165-178.

The Association of Graduate Recruiters. (1993). Roles for Graduates in the $21^{\text {st }}$ Century. Cambridge: AGR.

The Association of Graduate Recruiters. (1995). Skills for Graduates in the $21^{\text {st }}$ Century. Cambridge: AGR.

Toohey, S., Ryan, G. \& Hughes, C. (1996). Assessing the practicum. Assessment and Evaluation in Higher Education, 21(3), pp. 215-227. 
Table 1: Demographic data from survey results

\begin{tabular}{|l|c|}
\hline \multicolumn{1}{|c|}{ Demographics } & Stage 4 \\
\hline Sample size & 664 \\
\hline No. of responses & 164 \\
\hline Response rate & $25.7 \%$ \\
\hline School of Microelectronic Engineering & 41 \\
\hline School of Criminology and Criminal Justice & 26 \\
\hline School of Leisure Studies & 97 \\
\hline Female & 78 \\
\hline Male & 81 \\
\hline Age at graduation: & \\
19-21 & 18 \\
22-25 & 89 \\
26-30 & 28 \\
Over 30 & 22 \\
\hline Year of graduation: & \\
1997 & 31 \\
1998 & 40 \\
1999 & 42 \\
2000 & 51 \\
\hline Further study & 67 \\
\hline Completion of further study & 25 \\
\hline Employment: & \\
Up to one year & 52 \\
Up to two years & 33 \\
Two years or more & 68 \\
Unemployed & 9 \\
Number of graduates in employment relevant to & 117 \\
their field of study (N = 149) & \\
\hline
\end{tabular}


TABLE 2

Griffith Graduate Stage 4 Summary of responses to 11 survey questions using 5 point Likert scale, and one Yes/No item

\begin{tabular}{|c|c|c|c|c|c|c|}
\hline Survey Question & $\begin{array}{l}\text { \% } \\
\text { Strongly } \\
\text { Disagree }\end{array}$ & \% Disagree & $\begin{array}{c}\% \\
\text { Unsure }\end{array}$ & $\begin{array}{c}\% \\
\text { Agree }\end{array}$ & $\begin{array}{c}\text { \% Strongly } \\
\text { Agree }\end{array}$ & $\begin{array}{l}\text { No. of } \\
\text { Responses }\end{array}$ \\
\hline $\begin{array}{l}\text { 1. When I was at university it seemed more important for my future career prospects } \\
\text { to acquire content knowledge related to my degree than to develop my generic skills } \\
\text { and abilities. }\end{array}$ & $8.2 \%$ & $47.1 \%$ & $11.3 \%$ & $29.6 \%$ & $3.8 \%$ & 159 \\
\hline $\begin{array}{l}\text { 2. I did not have sufficient opportunities to develop generic skills and abilities during } \\
\text { my undergraduate degree. }\end{array}$ & $12.4 \%$ & $66.5 \%$ & $5.5 \%$ & $13.6 \%$ & $2.0 \%$ & 161 \\
\hline $\begin{array}{l}\text { 3. University teaching staff made me aware of the importance of generic skills and } \\
\text { abilities during my undergraduate degree. }\end{array}$ & $4.3 \%$ & $17.4 \%$ & $13.1 \%$ & $55.9 \%$ & $9.3 \%$ & 161 \\
\hline $\begin{array}{l}\text { 4. My university work placement was more important for enhancing my prospects } \\
\text { for employment after graduation than for developing my generic skills and abilities. }\end{array}$ & $3.8 \%$ & $49.7 \%$ & $9.4 \%$ & $26.4 \%$ & $10.7 \%$ & 159 \\
\hline $\begin{array}{l}\text { 5. My university work placement did not provide sufficient opportunities for me to } \\
\text { develop my generic skills and abilities. }\end{array}$ & $23.1 \%$ & $59.4 \%$ & $6.2 \%$ & $9.4 \%$ & $1.9 \%$ & 160 \\
\hline $\begin{array}{l}\text { 6. At university I was required to reflect on how my university work placement } \\
\text { contributed to the development of my generic skills and abilities. }\end{array}$ & $2.5 \%$ & $10.7 \%$ & $15.1 \%$ & $58.5 \%$ & $13.2 \%$ & 159 \\
\hline $\begin{array}{l}\text { 7. During my university work placement I was required to apply the generic skills } \\
\text { and abilities learnt in my undergraduate degree. }\end{array}$ & $1.9 \%$ & $11.4 \%$ & $8.2 \%$ & $59.5 \%$ & $19.0 \%$ & 158 \\
\hline $\begin{array}{l}\text { 8.It is important for me to continue to develop my generic skills and abilities in the } \\
\text { workplace as an employee. }\end{array}$ & $1.3 \%$ & $0.7 \%$ & $0.0 \%$ & $25.7 \%$ & $72.3 \%$ & 148 \\
\hline $\begin{array}{l}\text { 9. My employer creates sufficient opportunities for me to further develop my generic } \\
\text { skills and abilities in the workplace. }\end{array}$ & $4.9 \%$ & $8.9 \%$ & $9.0 \%$ & $44.1 \%$ & $33.1 \%$ & 145 \\
\hline $\begin{array}{l}\text { 11. My place of employment after graduation was so different from university that it } \\
\text { was hard for me to apply the generic skills and abilities that I had developed at } \\
\text { university. }\end{array}$ & $17.3 \%$ & $55.3 \%$ & $8.1 \%$ & $14.0 \%$ & $5.3 \%$ & 150 \\
\hline $\begin{array}{l}\text { 12. My development of generic skills and abilities during university work placement } \\
\text { gave me a definite advantage when it came to finding employment after graduation. }\end{array}$ & $7.6 \%$ & $10.1 \%$ & $22.8 \%$ & $43.7 \%$ & $15.8 \%$ & 158 \\
\hline \multicolumn{4}{|l|}{ Survey Question } & Yes & No & $\begin{array}{c}\text { No. of } \\
\text { Responses }\end{array}$ \\
\hline \multicolumn{4}{|c|}{$\begin{array}{l}\text { 14. Do you believe that the generic skills and abilities developed as a result of your university work placement have contributed to } \\
\text { advancement in your career? }\end{array}$} & $74.2 \%$ & $25.8 \%$ & 155 \\
\hline
\end{tabular}


